\title{
DÜNYADA CEZA İNFAZ KURUMLARININ ÖZEL SEKTÖR TARAFINDAN YÖNETILLMESİ UYGULAMALARI
}

\author{
Vehbi Kadri KAMER*
}

\section{$\ddot{O} Z$}

Ceza infaz kurumlarl; mahkemelerce verilen tutuklama tedbir kararlarının veya hapis cezalarının infaz edildiği kurumlar olarak tanımlanabilir. Bu kurumlar ile ilgili başta penoloji, kriminoloji, sosyoloji ve psikoloji olmak üzere birçok bilim dalı çalışma yapmaktadır. Bu çalışmalar arasında özel sektör tarafindan yönetilen ceza infaz kurumlarının ayrı bir önemi bulunmaktadır. Tarihte ilk özelleştirilmiş hapishane uygulaması Kral II. Henry Döneminde 1166 yılında Ingiltere'de her şehirde "Goal”" adı verilen tesislerin kurulması ile ortaya çıkmıştır. Daha sona bu uygulamanın; Bridewells adı verilen hapishaneler, borçluların barındırıldı̆̆ hapishaneler ve başka bir yere hükümlü nakli şeklinde devam etmiştir. 1960'll yıllarda; Dünya'da suç ve ceza politikalarının değişmesi ayrıca işlenen suç sayısının artması ile bir yandan ceza infaz kurumlarında bulunan hükümlü ve tutuklu sayısı yükselmiş, diğer yandan ceza infaz kurumlarının yapım ve işletim maliyetleri artmıştır. Bu sorunun çözümü amacıyla; özel sektör tarafindan ceza infaz kurumlarının inşa edilerek yönetilmesi veya bu kurumlardaki yemek ve hükümlü nakli gibi bir takım hizmetlerin özel sektör tarafindan verilmesi modeli geliştirilmiştir. Bu Modelin ilk örneği Amerika Birleşik Devletleri'nde uygulamaya geçtikten sonra Avustralya ve Ingiltere başta olmak üzere birçok ülkede ceza infaz kurumları özel sektör tarafindan yönetilmeye başlamıştır. Bu modelin uygulanma şekli ülkeden ülkeye farklılık göstermiştir.

Anahtar Kelimeler: ceza infaz kurumlarl, hükümlü, infaz, özel sektör, rehabilitasyon.

\section{PRACTICES OF PENAL INSTITUTIONS MANAGED BY THE PRIVATE SECTOR AROUND THE WORLD}

\section{ABSTRACT}

Penal institutions could be defined as the institutions where the ones about whom the courts rule detention order or imprisonment sentence serve these imposed orders and sentences. Various fields, especially penology, criminology, sociology and

\footnotetext{
* Dr. Cumhuriyet Savc1sı. Yargitay Binası, Balgat / ANKARA

e- posta: vehbikadrikamer@gmail.com

ORCID: 0000-0002-8752-3466

DOI : 10.34246/ahbvuhfd.979204
}

Yayın Kuruluna Ulaştığı Tarih $\quad$ : 09/03/2021

Yayınlanmasının Uygun Görüldüğü Tarih: 22/06/2021 
psychology conduct studies on these institutions. The penal institutions managed by the private sector have a special place among these studies. The first privatized prison example of the history emerged upon the establishment of the institutions named "Goal" in every city across the England in 1166 during the reign of the King Henry II. Then, this practice was continued also through the prisons named Bridewells, the prisons where the debtors were kept, and in the form of transfer of the convicts to another place. In the 1960s, as a result of the change in the crime and punishment policies around the world, on the one hand the number of the convicts and detainees in the penal institutions increased, on the other hand, the construction and operating costs of the penal institutions increased. For the solution of this problem, the model was developed for managing the penal institutions by the private sector or provision by the private sector of some services such as the food service and the transfer of convicts. The first example of this model was carried out in the United States of America, and then the penal institutions were started to be managed by the private sector in many countries especially in Australia and the United Kingdom. The practice method of this model varies across the countries.

Keywords: penal institutions, convict, execution, private sector, rehabilitation.

\section{GİRIŞ}

Dünyada en yüksek maliyetli yatırımlardan birinin ceza infaz kurumlarının inşa edilmesi ve bu kurumları işletilmesi olduğu tespit edilmiştir. Bu kapsamda; Finlandiya'da ceza infaz kurumunda bulunan bir hükümlünün bir günlük maliyetinin 167 Avro iken, elektronik takip ile evde denetimin bir günlük maliyetinin 60 Avro ve diğer kamusal cezaların bir günlük maliyetinin 14 Avro olduğu belirlemiştir. Yapılan araştırmalarda ceza infaz kurumlarının maliyetinin, hükümlü ve tutuklu sayısı ile bunların ceza infaz kurumlarında kalma süreleriyle doğru orantılı olduğu belirlenmiştir. Ceza infaz kurumlarının maliyetinin azaltılması ile ilgili en önemli çözüm hapis cezasına alternatif yaptırımların geliştirilmesi olsa da, günümüzde tehlikeli hükümlüler başta olma üzere bir kısım hükümlü grupları için ceza infaz kurumları gerekliliğini korumaktadır. $\mathrm{Bu}$ nedenle ceza infaz kurumlarının maliyetini azaltacak politikaların geliştirilmesine ihtiyaç bulunmaktır. ${ }^{1}$

Yapılan araştırmalarda Dünyada ceza infaz kurumlarında bulunan

1 ELENA KANTOROWICZ ve ANDRİ WIBISANA, Rotterdam Institute of Law and Economics (RILE) Working Paper Series, 2014, s.2, (https://papers.ssrn.com/sol3/papers. cfm?abstract_id=1116188, erişim tarihi; 24.02.2021). 
hükümlü ve tutuklu sayısının hızlı bir şekilde yükseldiği ve 2000-2018 yılları arasında bu sayının \% 24 oranında artarak 10.740 .000 kişiye ulaştığ belirlenmiştir. Bu hükümlü ve tutukluların \% 90'ınından fazlasının 50 farklı ülkede bulunduğu tespit edilmiştir. 50 ülkenin 17'sinde farklı modellerde ve sayılarda ceza infaz kurumlarının özel sektör tarafından yönetildiği görülmektedir. ${ }^{2}$ Dünya nüfusunun \% 5'ine sahip Amerika Birleşik Devletleri'nde Dünyadaki ceza infaz kurumlarında bulunan toplam hükümlü ve tutuklu sayısının \% 25'i bulunmaktadır. Bu Ülkede bulunan hükümlü ve tutuklu sayısı Japonya'nın 14 ve Norveç'in 10 katına tekabül etmektedir. ${ }^{3}$ Dünyada olduğu gibi Avrupa Birliği ülkelerinde de ceza infaz kurumlarının mevcudu artmaktadır. Bu kurumlarda; İngiltere'de 84.614, Polonya'da 84.156, İspanya'da 67.047, Fransa'da 65.848, İtalya'da 65.701, Portekiz'de 13.614, Yunanistan'da 12.475 ve Latvia'da 6.063 hükümlü ve tutuklunun bulunduğu, ceza infaz kurumunda bulunan hükümlü ve tutuklu sayısının 100.000 ülke nüfusuna oranının, Latvia'da 297, Polonya'da 222, İspanya'da 147,46, İngiltere'de 132,9, Portekiz'de 129, İtalya'da 110,54, Yunanistan'da 110,53 ve Fransa' da 101,5 olduğu, ceza infaz kurumlarının mevcudunun bu kurumların kapasitesine oranının, İtalya'da \% 140, Yunanistan'da \% 126, Fransa'da \% 118, Portekiz'de \% 113, Polonya'da \% 98, İngiltere'de \% 96, İspanya'da \% 92 ve Latviya'da \% 76 olduğu tespit edilmiştir. ${ }^{4}$

Dünya Ceza Adalet Sisteminde; adliyeler, ceza infaz kurumları ve denetimli serbestlik müdürlükleri için bina yapılması ve bu binalardaki elektronik sistemlerin kurulması için ayrılan bütçeler dikkate alındığında, bu alanda büyük bir ticari pazarın olduğu ve bu pazarda sınırlı sayıda uluslararası şirketin söz sahibi bulunduğu görülmektedir. Bu pazarın tahmini bütçesinin 1997'de 360 milyar dolar ve 2004 yılında 424 milyar dolar olduğu değerlendirilmektedir. $\mathrm{Bu}$ bütçe içinde ceza infaz kurumlarının payının 62.5 milyar dolar olduğu tespit edilmiştir. ${ }^{5}$ Bu kapsamda Amerika Birleşik

JAMES BYRNE, KIMMBERLY R. KRAS, LINAAMARİAMARMOLEJO, 2019, International perspectives on the privatization of corrections, s.479, (https://spa.sdsu.edu/documents/ Byrne_et_al-2019-Criminology_Public_Policy.pdf, erişim tarihi; 24.02.2021).

3 KSENIJA BUTORAC, DİJANA GRACIN ve NEBOJŠA STANIĆ, 2017, The Challenges In Reducing Crımınal Recidıvısm, s.116, (https://bib.irb.hr/datoteka/912525.Butorac_et_ al.pdf, erişim tarihi; 24.02.2021).

4 ALESSANDRO MACULAN, DANIELA RONCO, FRANCESCA VİANELLO, Prison in Europe: Overview And Trends, 2013, s.13, (http://www.prisonobservatory.org/upload/ PrisoninEuropeOverviewandtrends.pdf, erişim tarihi; 24.02.2021).

5 CODY MASON, International Growth Trends in Prison Privatization, 2013, s.4, (https:// sentencingproject.org/wp-content/uploads/2015/12/International-Growth-Trends-in-Prison- 
Devletleri'nde ceza infaz kurumlarına yapılan harcama miktarı 1980 ile 2000 yılları arasında 7 milyar dolardan 57 milyar dolara yükselmiş, suç oranlarının sabit olmasına rağmen 2007 yılında bu rakam 70 milyar doların üzerine çıkıştır. ${ }^{6}$

Batı Dünyasında; özel sektör tarafından yönetilen ceza infaz kurumlarında bulunan hükümlü ve tutuklu sayısının ülke nüfusuna oranı dikkate alındığında Amerika Birleşik Devletleri ve İngiltere'nin bu sistemin uygulanmasında küresel lider oldukları görülmektedir. 2001 yılı sonu itibariyle Amerika Birleşik Devletleri'nde federal ve yerel ceza infaz kurumlarında bulunan yetişkin hükümlü ve tutukluların \% 6.5 'ini oluşturan 90.000 hükümlü ve tutuklunun özel sektör tarafından yönetilen ceza infaz kurumlarında barındırıldığ 1 tespit edilmiştir. İngiltere'de, Haziran 2001 itibariyle yetişkin hükümlü ve tutukluların \% 9.4'ünü oluşturan 6.000'den fazla hükümlü ve tutuklunun özel sektör tarafından yönetilen ceza infaz kurumlarında bulunduğu anlaşılmıştır. Bu iki ülke dışında; İskoçya, Hollanda, Avustralya, Yeni Zelanda, Güney Afrika ve Kanada da özel sektör tarafindan yönetilen ceza infaz kurumları ile ilgili uygulamaların başladığı, İrlanda Cumhuriyeti, Letonya, Sırbistan, Malezya, Filipinler, Güney Kore, Tayvan, Tayland, Tanzanya, Kosta Rika, Jamaika ve Panama gibi ülkelerde de bu konuda çalışmaların olduğu görülmektedir. Sonuç olarak yirmi yıldan kısa zaman içinde özel sektör tarafından yönetilen ceza infaz kurumlarının Dünya infaz sistemi içinde önemli bir yere sahip olduğu anlaşılmaktadır. ${ }^{7}$

Ceza infaz kurumlarının özel sektör tarafından yönetilmesi sisteminin Dünya uygulamalarına bakıldığında kıtalar arasında farklılıklar görülmektedir. Özel sektör tarafından yönetilen ceza infaz kurumlarında en fazla hükümlü ve tutuklu barındıran ülkeler değerlendirildiğinde; Amerika Kıtasında (Kuzey, Orta, Güney ve Karayipler) 12 ülkenin 9'unda ve Asya Kıtasında 16 ülkenin 2'sinde (Güney Kore Cumhuriyeti ve Japonya) ceza infaz kurumlarının özel sektör tarafından yönetildiği anlaşılmaktadır. ${ }^{8}$

Privatization.pdf, erişim tarihi; 23.02.2021).

6 LEVENT ODABAȘI, Cezaevi Endüstrileri ve Cezaevi Özelleştirilmesi, Ankara Üniversitesi Sosyal Bilimler Enstitüsü Siyaset Bilimi ve Kamu Yönetimi (Siyaset Bilimi) Yayınlanmamış Yüksek Lisans Tezi, 2016, s.122.

7 DAVID POZEN, Managing a Correctional Marketplace: Prison Privatization In The United States and The United Kingdom, 2004, s.253, (https://scholarship.law.columbia.edu/ faculty_scholarship/1305, erişim tarihi; 24.02.2021).

8 JAMES BYRNE, KIMBERLY R. KRAS, LINA MARIA MARMOLEJO, International 
Bu makalede; Dünyadaki İnfaz Sistemlerindeki gelişmelere uygun olarak özel sektör tarafından yönetilen ceza infaz kurumlarının ortaya çıkışı, bu alanda uygulanan modeller ve bu sistemin sonuçları ile ilgili değerlendirmeler incelenecektir.

\section{DÜNYA TARİHINNDE HAPISSHANELERİN DOĞUŞU}

Dünya tarihinde hapishanelerin doğuşu hakkında açıklamalarda bulunmadan önce, hapis cezası ile ilgili teorilerin genel olarak incelenmesi gerekmektedir. Kriminoloji ve Penolojide, cezanın felsefesi konusunda çok sayıda teori geliştirilmiştir. Bu çalışmalara kısaca baktığımızda sosyoloji biliminin kurucusu olarak görülen Durkheim toplum biçimleri ile cezalandırma yöntemleri arasında bir bağlantının olduğunu ileri sürmüş, Speirernberg ve Garland ise bu düşünceyi temel alarak suça sürüklenen bireyin topluma kazandırılması yöntemleri ile toplumsal kültür arasında seçim bölgesi olduğuna odaklanmıştır. Disiplin ve Ceza: Ceza İnfaz Kurumlarının Doğuşu isimli eserinde Michael Foucault cezalandırma yöntemleri ile toplum yapısı arasındaki güçlü ilişkiyi ortaya koymuştur. Foucault cezalandırma olgusunu; bu konudaki teorileri, kurumları, uygulamaları, kanunları ve uygulayıcıları içine alacak şekilde geniş bir bakış açısı ile incelemiştir. ${ }^{9}$

Ünlü kriminolog ve bilim adamı Hudson; bu konuda Durkheim'ci ve Foucault'cu açıklamaların analizini yaparak, toplumların sosyal ve ekonomik doğası ile ceza biçimleri arasında bağlantıyı açıklamaya çalışmıştır. Hudson'a göre, tarihin belirli dönemlerinde belirli ceza biçimlerinin ortaya çıkmasının sosyal ve ekonomik nedenleri bulunmaktadır. Hudson, Fransız Devrimi, sanayileşme, bilim ve teknolojinin gelişimi ve biyografik faktörlerin yanı sıra sosyolojik faktörlerin ceza sisteminin doğasını erken çağlardan modern çağlara değiştirmede etkisi olduğunu tespit etmiştir. ${ }^{10}$

Başka bir bilim insanı Alexander, ceza felsefesinin suç, suçluluk ve cezalandırmayı içine alacak biçimde değerlendirilmesi gerektiğini, bu felsefenin temel amacının tarihsel bir bakış açısıyla cezanın bir çağdan

Perspectives On The Privatization of Corrections, 2019, s.479, (https://spa.sdsu.edu/ documents/Byrne_et_al-2019-Criminology_Public_Policy.pdf, erişim tarihi; 24.02.2021).

9 NURJAHAN KHATUN, MOHAMMED JAHIRUL ISLAM, SUBRATA BANARJEE, MOUMITA PAUL, Philosophy of Punishment in Criminology: A Historical Review, 2013, s.4, (https://www.researchgate.net/publication/330113779_Philosophy_of_Punishment_in Criminology_A_Historical_Review, erişim tarihi; 24.02.2021).

10 KHATUN, ISLAM, BANARJEE, PAUL, a.g.m, s.4. 
diğerine değişiminde katkıda bulunan faktörleri ortaya çıkarmak olduğunu vurgulamıştır. ${ }^{11}$

$\mathrm{Bu}$ kısa açıklamadan sonra, suça sürüklenen bireylerin cezalandırma biçimlerinden biri olan hapishanelerin ortaya çıkışı ve tarihsel gelişim sürecine bakıldığında binlerce yıl öncesinde bu kurumların bulunduğu görülmektedir. Bu kapsamda; tarihte çukurların, zindanların ve mağaraların ilk hapishane uygulamaları olduğu tespit edilmiştir. Johnston, Konfüçyüs tarafından M.Ö. 2000'de yazılmış bir kitapta cezaya ilişkin hükümlerin bulunduğunu belirtmiştir. Harris, Mısır'da, Eski Asur'da, Babil'de, Antik Yunanistan'da ve Roma'da, köleler için daha sert fiziksel cezaların olduğunu, köle statüsünde olmayanların ise para cezası, sürgün, hapis veya bunların bazılarının birleştirilmesi ile cezalandırıldığını ifade etmiştir. ${ }^{12}$

Tarihin ilk döneminde ölüm cezası ile cezalandırılanlar genelde mermer veya metal ocaklarındaki ağır işlerde çalıştırılmaktaydı. Ölüm cezası dışındaki hapis cezaları; İngiliz şatolarda, "Gaoller"13 tarafından idare edilen Goalde (hapishanelerde) yerine getirilmekteydi. İngiltere'de; bin y1l önce ilk hapishanelerin uygulamalarının yaygın olarak kullanıldığı görülmektedir. $\mathrm{Bu}$ kapsamda; Dokuzuncu Yüzyılda Büyük Alfred tarafından yürürlüğe konulan kanun ile hapsetmenin cezalandırma yöntemi olarak kullanılmasının zorunlu k1lındığı, Kral II. Henry'in 1166 yılında Gaoller bulunmadığı yerlerde bir kişinin "şehri surlarla çevirerek ve kraliyet kalesi inşa ederek" yapacağ1 binalarda suç işleyenleri yargılamak amacıyla tutabileceği, Elizabeth Dönemi'nde hanciların tesislerini Gaol olarak kullanarak kâr elde etmek amacıyla kullandıkları anlaşılmaktadır. Elizabeth Dönemi'nde; hancılar veya diğer Gaoller tarafından işletilen hapishanelerde bulunan hükümlüler barınma ve yeme masraflarını ya para vererek yada çalışarak ödüyorlardı. Maddi durumu iyi hükümlüler hapsedildiklerinde ödeme yaparak daha iyi şartlarlarda kalabiliyorlardı. Bu konuda yapılan bir çalışmada; Marquis'in Bastille Hapishanesinde bulunduğu süre içinde buraya kendi mobilyalarını, resimlerini ve kütüphanesini getirdiği, bir uşağının bu kurumda kaldığı, ayrıca

11 KHATUN, ISLAM, BANARJEE, PAUL, a.g.m, s.4.

12 MATT DELISI, PETER J CONIS, American Corrections: Theory, Research, Policy, and Practice, s.58, (https://us.sagepub.com/sites/default/files/upm-assets/94917_book_ item_94917.pdf, erişim tarihi; 24.02.2021).

13 Goller ile ilgili ayrıntılı bilgi bu Ülkedeki özel sektör yönetiminde ceza infaz kurumlarının tarihçesi bölümlerinde ayrıntılı olarak açıklanmıştır. 
eşinin de zaman zaman kendisine yemek getirdiği belirtilmektedir. ${ }^{14}$ Tarihe bakıldığında İngiltere'deki Goallerin ilk özel sektör tarafından yönetilen hapishane uygulaması olduğu kabul edilmektedir.

Avrupa kıtasında; Katolik Kilisesinde görevli piskoposlar veya diğer kilise yetkilileri tarafindan yönetilen hapishaneler veya bu kurumlara benzer tesisler bulunuyordu. Kilisenin; Orta Çağda Beşinci Yüzyıldan Onbeşinci Yüzyıla kadar batı türü hapishanelerin gelişimi konusundaki etkisi güçlüydü. Manastırlarda hükümlüler barındırılmakta ve cezalandırılmakta iken, kiliselerde, hükümlülere uzun süreli yalnızlık, azaltılmış besin ve derinlemesine düşünmeyi içeren cezalandırma yöntemleri uygulanmaktaydı. Bu uygulamanın etkisi ile Amerika Birleşik Devletleri'ndeki ve Avrupa'daki hapishanelerde Katolik Kiliselerindeki sessizlik uygulaması aynen alınarak, hükümlerin pişmanlıklarını gösterebilecekleri küçük ve sade odalardan oluşan hapishanelerde barındırılmaya başladıkları görülmüştür. Mimari açıdan bu anlayışa uygun hapishaneler planlanmaya başlanmıştır. ${ }^{15}$

Cezalandirma yöntemlerinin tarihsel süreci; bedensel cezalar ve ilk hapishanelerin faaliyete geçmesinden sonra "Kadırga Köleliği" uygulamaları ile devam etmiştir. $\mathrm{Bu}$ cezalandırma yöntemi Eski Yunanlılarda ve Romalılarda nadiren uygulanmakta iken, Orta Çağın sonlarında Avrupa ve İngiltere'de yaygın olarak 1700'lü yıllara kadar uygulanmıştır. Bu dönemde I. Elizabeth 1602 yılında Kadırga Köleliğinin ölüm cezasına alternatif olarak uygulanacağını kararlaştırmıştır. Kadırga Köleliği; bir yandan sokakta yaşayan kişilerin işledikleri suçlar ile ilgili bir cezalandırma yöntemi olarak uygulanırken, diğer yandan denizcilik yapan Devletlerin ticaret ve savaş durumlarında gemilerini hareket ettirmeleri için gereken işgücünü sağlama biçimi olmuştur. Ayrıca bu yöntemin Columbus tarafından kullanıldığ 1 bilinmektedir. Kadırga Köleliği cezalandırma biçiminin süresi üç yıldan ömür boyuna kadar değişiyordu. ${ }^{16}$

Avrupa'da devam eden savaşlarda ve veba salgınında çok sayıda kişi hayatını kaybetmesine rağmen nüfusun hızlı biçimde artış gösterdiği, bunun sonucu başta yoksulluk, işsizlik ve açlık gibi sorunların ortaya çıtığı, yoksul insanların kentlere göç etmeye başladığı görülmüştür. Bu Dönemde; ölüm ve hapis cezası uygulamalarının yaygın hale geldiği, yargılama aşamalarında

\footnotetext{
14 DELİSI, CONIS, a.g.m, s.58.

15 DELİII, CONIS, a.g.m, s.58.

16 DELİSI, CONIS, a.g.m, s.58.
} 
sanığın hazır bulundurulması amacıyla tutuklama tedbirinin sıkça uygulandığı, sonuçta yoksul evlerinin, Bridewells adı verilen hapishanelerin ve borçluların barındırıldığı hapishanelerin (debtors' prison) sayısında artış olduğu ayrıca başka bir yere hükümlü nakli (transportation) uygulamalarında yoğunluk yaşandığ1 anlaşılmıştır. Onsekinci Yüzyıl İngiltere'sinde 225 suç için ölüm cezas1 öngörülmüştü. Uygulamada hakimler en ağır cezay1 verme yerine, başka bir yere hükümlü nakli, kırbaçlama ve damgalama cezalarını tercih etmişlerdir. 1700'lü yılların ikinci yarısından itibaren hapis cezası diğer cezaların yerine veya bu cezalara ek olarak uygulanmaya başlanmıştır. ${ }^{17}$

Bridewells; 1553 yılında Londra'da önce dilencilerin barındırıldığ binalar olup, daha sonra tutuklu kişilerin barındırıldığ yerler olarak kullanılmaya başlanmıştır. İlk Bridewells, St. Bridget's Well adresinde faaliyete geçmesi nedeniyle bu adresin kısaltması olarak bu isim verilmiştir. Ayrıca Bridewells, para cezaları veya borcun ödenmesi için "çalışma evi" olarak faaliyet göstermiştir. Bu kurumda kalanlar; cinsiyet, yaş ve suç türüne göre sınıflandırılmamış diğer ifade ile birbirinden ayrılmamış, ayrıca hükümlülere yeterli beslenme ve kıyafet ile temizlik koşulları sağlanmamıştı. Bridewells'lerin fiziki koşulları değerlendirildiğinde tehlikeli ve sağlıksız yerler olup, burada bulunan kişilerin tükettikleri yiyecek, kullandıkları giyecek ve salıverilmeleri için ücret ödemesi gerekiyordu. Bu ücretin ödenmemesi halinde kendisi ve ailesi ayrıca mahkûmiyet hükmü alabiliyordu. Avrupa'da ve İngiliz Koloni'lerinde Bridewells'ler, bir yandan kar eden kurumlar olmas1, diğer yandan yoksulları sokaktan uzaklaştırması nedeniyle hızlı bir şekilde yaygınlaşmıştır. ${ }^{18}$

Avrupa Devletleri tarafindan Amerika Kitasında 1607 Virginia Kolonisi'nin kurulmasından sonra buraya hükümlü göndermek suretiyle "transportation (başka bir yere hükümlü nakli)" cezalandırma yöntemi uygulanmaya başlanmıştır. Şehirleri yoksullardan ve suça eğilimli kişilerden korumak amaciyla kurulan Bridewells ve Gaoller gibi hapishanelerin yanında başka bir yere hükümlü nakli (transportation) cezalandırma türü de bir özel sektör tarafından uygulanan cezalandırma şekliydi. Bu uygulamada hükümlü gemi kaptanına satılmakta, kaptan da hükümlüyü sözleşmeli işçi olarak genellikle tarımsal faaliyetlerde çalışmak üzere Maryland, Virginia ve Georgia gibi Amerikan Kolonilerine veya Avustralya’ya ücret karşılı̆̆1 vermekteydi.

\footnotetext{
17 DELİSI, CONIS, a.g.m, s.58.

18 DELİSI, CONIS, a.g.m, s.58.
} 
Rusya Sibirya'ya, İspanya Hispaniola'ya, Portekiz Kuzey Afrika'ya, İtalya Sicilya'ya hükümlü naklederek bu cezalandırma türünü kullanmıştır. $\mathrm{Bu}$ uygulama; Amerika Birleşik Devletlerinde Bağımsızlık Savaşı sonunda, Fransa' da ise 1953 yılında kaldırılmıştır. ${ }^{19}$

İngiltere'de gemi kaptanları Amerikan Kolonilerine gönderilecek hükümlüler için Kraliyete hükümlü başına 1-6,5 sterlin ücret ödemekteydi. $\mathrm{Bu}$ ücret hükümlünün nakilden önceki hapishanedeki barınma masrafını karşılamaktaydı. Hükümlünün Amerikan Kolonilerine götürülmesinin maliyeti 6,05 sterlin civarında olduğu tahmin edilmektedir. Bu karşılık hükümlü Amerikan Kolonisinde ortalama 15 Sterline arazi sahiplerine verilmekte dolayısı ile gemi kaptanları bir hükümlüden \% 150 oranında kar etmekteydi. İngiltere'de bu yöntemle 50.000 hükümlü Amerika Kolonilerine nakledilmiştir. ${ }^{20}$

Başka bir yere hükümlü nakli (transportation) yöntemiyle cezalandırma türünün yerine getirildiği ceza kolonileri ile ilgili en ayrıntılı bilgi Avustralya'nın 1.000 mil açıklarında bulunan Norfolk Adası hakkındadır. İngiltere'den ve Avustralya'dan gönderilen hükümlüler için 1788 yılında bu Adada kurulan ceza kolonisinde (hapishanesinde); hükümlüler yetersiz beslenmekte ve giydirilmekte ayrıca kötü koşullarda barındırılmakta, personel ve eski hükümlüler tarafindan yeni gelen hükümlülere kötü muamele uygulanmaktaydı. Hiç kimsenin görev yapmayı tercih etmediği Norfolk Adası Hapishanesinde, eski bir gemi kaptanı olan Alexander Maconochie düşündüğü hapishane reformunu uygulamaya geçirmek amacıyla çalışmak istemiştir. 1840-1844 yılları arasında bu hapishanede gardiyan olarak görev yapan Maconochie, tarihin en kötü koşullara sahip bu hapishaneyi son derece kontrollü, istikrarlı ve üretim yapılan bir yer haline dönüştürmüş ve bu olağanüstü başarı nedeniyle hapishaneden salıverilen hükümlüler "Maconochie'nun Centilmenleri” olarak anılmıștır. Hükümlülere saygılı davranılması, yeterli beslenme imkanı sağlanması ve iyi koşullarda barındırılması gerektiğine inanan Maconochie'nun başarısının altında yatan temel felsefe; hükümlülerin hapishaneden erken salıverilmeleri veya hapishanede bulundukları süre içinde ayrıcalıklara sahip olabilmeleri için

19 DELİSI, CONIS, a.g.m, s.58.

20 HILLAL GÖRKEM, Kamu Hizmetlerinin Özelleştirilmesi Kapsamında Cezaevi Hizmetlerinin Özelleştirilmesi ve Türkiye'de Uygulanabilirliği, Ankara, 2009, s.10. 
geliştirdiği bir puanlama sistemi $i^{2 l}$ dir. $\mathrm{Bu}$ Sistemle hükümlülerin olumlu davranışları ödüllendirilmiştir. Maconochie'nun fikirleri on yıllar sonra İrlanda ve Amerika Birleşik Devletleri'nde koşullu salıverme kavramlarının gelişiminden sonra kabul görmüştür. Ayrıca Maconochie'nun hükümlülerin yeterince beslenmesi ve giydirilmesi konusundaki görüşleri John Howard ve William Penn gibi reformcular tarafindan benimsenmiştir. ${ }^{22}$

\section{DÜNYADA CEZA İNFAZ KURUMLARINDA ÖZEL SEKTÖR UYGULAMALARI}

Dünyada ceza infaz kurumlarının özel sektör tarafından yönetilmesi ile ilgili çalışmalar incelendiğinde üç farklı modelin olduğu anlaşılmaktadır. Bunlar; Amerika Birleşik Devletleri Modeli, Fransa Modeli ve Brezilya Modelidir. Bu üç modelde, özel sektörün ceza infaz kurumlarının yönetimine katılım oranı ve şekli değişmektedir. Örneğin Amerika Birleşik Devletleri’nin bazı eyaletlerinde özel sektör ceza infaz kurumlarını tam yönetmekte ve ceza infaz kurumundaki bütün çalışmalar özel sektör tarafindan gerçekleşmekte iken, Brezilya ve Fransa'da özel sektörün bu kurumların yönetime katılımı sınırlı olmakta ayrıca ceza infaz kurumundaki çalışmaların bir kısmı özel sektör tarafindan yerine getirilmektedir. Yine Brezilya ile Fransa karşılaştırdığında Fransa'da daha dar kapsamlı özel sektör çalışmaları söz konusu olduğu görülmektedir. Diğer yandan bu üç ülkenin ceza politikalarında da farklılık olduğu anlaşılmaktadır. ${ }^{23}$

Amerika Birleşik Devletleri'nde, Brezilya ve Fransa'ya oranla toplum için tehlike oluşturmayan kişilerin daha fazla ceza infaz kurumlarında bulunduğu görülmektedir. 100.000 ülke nüfusu dikkate alındığında Amerika Birleşik Devletleri'nde 754, Brezilyada 200 ve Fransa'da 96 kişinin ceza infaz kurumlarında bulunduğu anlaşılmaktadır. Diğer yandan bu üç ülkenin kamu ile özel sektör arasında yapılan ceza infaz kurumlarının yönetimi konusunda yapılan sözleşmelerin sonuçları incelendiğinde teorik tahminlerden farklı olarak değişik sonuçların ortaya çıktığı görülmektedir. Bu kapsamda;

${ }^{21}$ Yıllar sonra bu çalışma geliştirilerek Dünyanın hemen hemen her yerindeki ceza infaz kurumlarında "Hükümlü Değerlendirme Sistemi” olarak uygulamaya geçmiştir.

22 DELİSİ, CONIS, a.g.m, s.58.

23 SANDRO CABRAL ve STÉPHANE SAUSSIER, Organizing Prisons Through PublicPrivate Partnerships: A Cross Country Investigation, 2012, s.102, (https://www.researchgate. net/publication/262665166_Organizing_Prisons_through_Public-private_Partnerships_A Cross-Country_Investigation/link/0395bde90ef2005ef799de40/download, erişim tarihi; 24.02.2021). 
Brezilya'da ceza infaz kurumlarının özel sektör tarafından yönetiminin bu kurumların maliyetini düşürdüğü aynı zamanda bu kurumlarda sunulan hizmetlerin kalitesini artırdığı, bu karşılık Fransa'da bu sistemin hem ceza infaz kurumlarının maliyetini artırdığı aynı zamanda bu kurumlarda sunulan hizmetlerin kalitesini yükselttiği görülmüştür. Brezilya ve Fransa'daki uygulamaların aksine Amerika Birleşik Devletlerinde ceza infaz kurumlarının özel sektör tarafından yönetiminin bu kurumların hem maliyetini hem bu kurumlarda sunulan hizmetlerin kalitesini azalttığı tespit edilmiştir. ${ }^{24}$

Amerika Birleşik Devletleri'nde, İngiltere'de, Fransa'da, Avustralya'da, Yeni Zelanda'da, Güney Afrika Cumhuriyeti'nde, Macaristan'da ve Brezilya'da özel sektör tarafından yönetilen ceza infaz kurumlarının tarihçesi incelenecektir.

\section{A. Amerika Birleşik Devletleri'nde Ceza İnfaz Kurumlarında Özelleştirme Uygulamaları}

19'uncu yüzyılda Amerika Birleşik Devleri'nde ceza infaz kurumlarında bulunan hükümlülerin ekonomik bakımdan istismarı yaygın olarak görülmekteydi. İç savaş sonrası bu Ülkenin güney eyaletlerinde sanayide ve tarımsal alanlarda yeterli sayıda işçi bulunamaması nedeniyle ceza infaz kurumlarında bulunan hükümlüler; bir yandan demiryolu inşaatı, madencilik ve kereste üretimi gibi işgücünün yeterli olmadığ 1 alanlarda, diğer yandan özel sektörün işlettiği pamuk tarlalarında ve fabrikalarda çalıştırılmaya başlanmıştır. Medyanın, özel sektörün ceza infaz kurumlarındaki zorlu ve katı çalışma koşullarını ortaya çıkarması, ayrıca kamuoyunun baskısı ile bu çalışma modeline 1960'lı yılların başında son verilmiştir. ${ }^{25}$

Ceza infaz kurumlarındaki özel sektör çalışmaları, 1975 yılında RCA Şirketinin Pennsylvania Eyaletinde bulunan ve az sayıda çocuk hükümlünün bulunduğu bir çocuk ıslahevi ile anlaşma yapması sonucu tekrar başlanmıştır. Amerika Birleşik Devletleri'nde 1975 yılından itibaren yirminin üzerinde şirket, düşük ve orta risk taşıyan hükümlüler için yeni ceza infaz kurumlarının inşası ve bu kurumların işletilmesi için çalışmalara başlamıştır. 1990'lı yıllara gelindiğinde bu Ülkede bulunan ceza infaz kurumlarındaki hükümlü ve tutukluların \% 2'sini oluşturan 20.000 hükümlü ve tutuklu özel ceza infaz

${ }^{24}$ CABRAL VE SAUSSIER, a.g.m, s.102.

25 ALLAN BROWN, Economic Aspects Of Prison Privatisation: The Queensland Experience, s.104 (http://citeseerx.ist.psu.edu/viewdoc/download?doi=10.1.1.491.4922\&rep=rep1\&typ $\mathrm{e}=\mathrm{pdf}$, erişim tarihi; 24.02.2021). 
kurumlarında barındırılmıştır. ${ }^{26}$

1984 yılında Amerika Birleşik Devletleri'nde bu alanda Dünyanın en büyük firması olan "Correction Corporration of Amerika" kurulmuş, bu firma sahip olduğu 24 ceza infaz kurumunda 11.500 hükümlü barındırarak toplamda 100 milyon dolar ciro elde etmiştir. Bu firma dışında 1995 yılında faaliyete geçen "Wakenhut Corporration", 32.000 personeli ile Amerika Birleşik Devletleri ve 40 ayrı ülkede çalışmalarını sürdürmüş, yine "Esmor Correction Service" 53 ceza infaz kurumunda 30.000 yatak kapasitesini yönetmiştir. ${ }^{27}$

1980'li yılların sonuna gelindiğinde ceza infaz kurumlarının özelleştirilmesi konusunun akademisyenler, avukatlar ve politika yapıcıları arasında tartışmalara neden olduğu, bu dönemde ceza infaz kurumlarının mevcudunun inanılmaz bir şekilde arttı̆̆ 1 ve bu artışın karşılanması amacıyla yeni ceza infaz kurumlarının yapımına ihtiyaç duyulduğu anlaşılmıştır. Bu dönem ile ilgili olarak David Garland; Amerika Birleşik Devletleri ve Avrupa arasındaki suç politikalarında ve kamuoyunun beklentilerinde suça sürüklenen bireylerin rehabilitasyonu yerine bu bireyleri cezalandırmayı esas alan dramatik ve kapsamlı bir değişikliğin olduğunu ifade etmiştir. ${ }^{28}$

Özel sektör tarafından ceza infaz kurumlarının yönetilmesinin nedenlerini üç başlık altına özetleyebiliriz. Bunlardan birincisi ceza infaz kurumlarının mevcudunun artması, ikincisi bu artışın kamu maliyesi üzerindeki olumsuz etkisi ve üçüncüsü kamuoyunun sokak suçlar ${ }^{29}$ için daha etkili soruşturma ve bu suçlara daha uzun süreli hapis cezası verilmesine ilişkin talebi ile yeni ceza infaz kurumlarının yapılması nedeniyle artan vergi yükü konusundaki olumsuz psikolojisidir. ${ }^{30}$

26 BROWN, a.g.m, s.104.

27 TİMUR DEMİRBAŞ, İnfaz Hukuku, Seçkin Yayınevi, Ankara, 2003, s.436.

28 ALFRED C. AMAN, JR., CAROL, J. GREENHOUSE, "Prison Privatization And Inmate Labor In The Global Economy: Reframing The Debate Over Private Prisons", 2016, s.376, (https://ir.lawnet.fordham.edu/cgi/viewcontent.cgi?article=2561\&context=ulj, erişim tarihi; 24.02.2021).

29 Sokak suçu ifadesi, genellikle farklı türlere ayrılmakta, hem kamusal hem de özel alanlarda meydana gelen eylemlerin yanı sıra kişilere yönelik şiddet ve mülkiyet suçlarını içerebilmektedir. Amerika Birleşik Devletleri Adalet Bürosu'na göre sokak suçları; insan öldürme, cinsel istismar, saldırı ve kundaklama gibi şiddet içeren suçları içermektedir. SHANELL SANCHEZ, Street Crime, Corporate Crime, and White-Collar Crime, (https:// openoregon.pressbooks.pub/ccj230/chapter/1-12-different-types-of-crime-in-the-unitedstates/, erişim tarihi; 24.02.2021).

30 AMAN, CAROL, GREENHOUSE, a.g.m, s.376. 
Bu Ülkede suçla ilgili politik anlayışın değişmesi, ceza infaz kurumlarının kapasitesinin üzerinde hükümlü ve tutuklu barındırması ve hükümetin özelleştirmeyi teşvik etme kararına rağmen, özel sektör tarafından ceza infaz kurumlarının yönetilmesi seçeneğinin kabul edilmesi ve yaygınlaşması istenilen hızda olmamıştır. Bugün Amerika Birleşik Devletleri'ndeki ceza infaz kurumlarının yaklaşık \% 10'nu özel sektör tarafından yönetilmekte olup bu kurumlarda yaklaşık 200.000 hükümlü ve tutuklu barındırılmaktadır. $\mathrm{Bu}$ Ülkede başta California, Florida ve Teksas Eyaletlerinde olmak üzere 2001 yılına kadar 158 özel sektör tarafından yönetilen ceza infaz kurumu bulunmaktaydı. Özel sektör tarafından yönetilen ceza infaz kurumları başlangıçta yetişkin hükümler için düşünülmüş ancak zamanla çocuklar ve yasa dışı ülkeye giren göçmenleri de kapsamıştır. Yine çocuklar ve kayıtsız göçmenler için özel sektör tarafından yönetilen gözaltı merkezleri de geliştirilmiştir. ${ }^{31}$

31 Aralık 2008 tarihinde Amerika Birleşik Devletleri'nde eyalet ve federal ceza infaz kurumlarında bulunan hükümlü ve tutukluların $\% 8.5$ 'ini oluşturan 128.524 hükümlü ve tutuklu özel sektör tarafindan yönetilen ceza infaz kurumlarında barındırılmıştır. Eyaletler arası bu oranlar değişmekle beraber New Mexico Eyaletinde bu oran \% 46'ya ulaşmıştır. ${ }^{32}$

$\mathrm{Bu}$ Ülkede özel sektör tarafından yönetilen ceza infaz kurumlarında görev yapan personele ile kamu tarafindan yönetilen ceza infaz kurumlarında görev yapan personelin özlük hakları karşılaştırıldığında; 1998 yılında özel sektörün personelin kıdemine göre 15.919 dolar ile 19.103 dolar arasında ödeme yaptığ 1 ve kıdemli ile kıdemsiz personel arasında 3.184 dolar maaş farkının olduğu, kamunun ceza infaz kurumlarında görev yapan personele 21.246 dolar ile 34.004 dolar arasında ücret verdiği ve kıdemli ile kıdemsiz personel arasında 12.758 dolar maaş farkının bulunduğu görülmektedir. $\mathrm{Bu}$ rakamlar özel sektörün yeni işe alınan personele 5.327 dolardan daha az ödeme yaptığını göstermektedir. Ücretin yanında diğer önemli bir konu olan personelin eğitimi ile ilgili özel sektör, ceza infaz kurumu personeline göreve başlamadan önce 174 saat meslek öncesi eğitim ve göreve başladıktan sonra 42 saat hizmet içi eğitim verirken, kamu sektöründe, hizmet öncesi eğitimin süresi 232 saat ve hizmet içi eğitimin süresi 42 saat olarak gerçekleşmiştir. ${ }^{33}$

31 AMAN, CAROL, GREENHOUSE, a.g.m, s.376.

32 CABRAL VE SAUSSIER, a.g.m, s.106.

33 CURTIS R. BLAKELY, VIC W. BUMPHUS, Private and Public Sector Prisons-A 
Ceza infaz kurumlarının asayiş durumu değerlendirildiğinde; özel sektör tarafından yönetilen ceza infaz kurumlarında hükümlünün başka hükümlüye saldırı sayısı ortalamasının 40 ve hükümlünün personele saldırı sayısı ortalamasının 9 olduğu, kamu sektör tarafından yönetilen ceza infaz kurumlarında hükümlünün başka hükümlüye saldırı sayısı ortalamasının 19 ve hükümlünün personele saldırı sayısı ortalamasının 10 olarak gerçekleştiği tespit edilmiştir. ${ }^{34}$

Hükümlülerin topluma kazandırılması çalışmaları içinde ceza infaz kurumlarında sürdürülen rehabilitasyon çalışmalarının büyük yeri bulunmaktadır. $\mathrm{Bu}$ çalışmalar kapsamında madde bağımlılığından arınma ve öfke kontrol başta olmak üzere çok sayıda program uygulanmaktadır. ${ }^{35}$ Amerika Birleşik Devletleri'nde özel sektör tarafından yönetilen ceza infaz kurumlarında hükümlülerin \% 28'i madde bağımlılığından arınma müdahale programına katılırken kamu sektör tarafindan yönetilen ceza infaz kurumlarında bu oranın \% 10 seviyesinde kaldığ 1 belirlenmiştir. ${ }^{36}$

Ceza infaz kurumlarında meslek eğitim çalışmaları kapsamında hükümlülere; hem teorik hem pratik eğitim verilmekte, hükümlüler aldıkları bu eğitimi atölye ve tesislerde çalışarak geliştirilmekte, tecrübe kazanmakta ve ücret almaktadırlar. ${ }^{37}$ Amerika Birleşik Devletleri'nde özel sektör tarafindan yönetilen ceza infaz kurumlarında hükümlülere altıbuçuk saat çalışma karş1lığında günde 1.09 dolar ile 2.75 dolar arasında ücret ödenmekte iken, bu miktar kamu sektör tarafindan yönetilen ceza infaz kurumlarında 0,99 dolar ile 3.13 dolar arasında değişmektedir. ${ }^{38}$

Uzun yıllar süren çalışmalardan sonra Amerika Birleşik Devletleri'nde "Amerika Islah Derneği” tarafindan özel sektör tarafindan yönetilen ceza infaz kurumlarının fiziki yapısından hükümlülere uygulanan rehabilitasyon programlarına kadar uyulması gereken 463 standart belirlemiştir. $\mathrm{Bu}$

Comparison of Select Characteristics, s.4, (https://www.uscourts.gov/sites/default/ files/68_1_5_0.pdf, erişim tarihi; 24.02.2021).

34 BLAKELY, BUMPHUS, a.g.m, s.5.

35 VEHBİ KADRİ KAMER, "Ceza İnfaz Sisteminde "İyi Hâl” Kararı İle "Değerlendirme Raporu”-I”, Sesleniş Gazetesi, Say1:165, 2013, s.12.

36 BLAKELY, BUMPHUS, a.g.m, s.5.

37 VEHBİ KADRİ KAMER, "2015 Y1lı İlk Beş Ayında İşyurtları Kurumu”, Sesleniş Gazetesi, Sayı:158, 2015, s.12.

38 BLAKELY, BUMPHUS, a.g.m, s.5. 
standartlar arasında; personelin eğitimi, odaların fiziksel durumu ve temizliği, hükümlülere sağlanan yiyecek, iş ve eğitim olanakları bulunmaktadır. 463 standarttan 38'inin zorunlu olarak yerine getirilmesi gerekmektedir. $\mathrm{Bu}$ standartların \% 90'ının yerine getirilmesi halinde "Amerika Islah Derneği”" tarafindan özel sektöre "akreditasyon belgesi" verilmekte, bu belge üç y1lda bir yenilenmektedir. ${ }^{39}$

\section{B. İngiltere'de Ceza İnfaz Kurumlarında Özelleştirme Uygulamaları}

Ortaçağ İngiltere'sinde hapishaneler kâr elde etmek amaciyla işletilen kurumlardı. Bu Ülkede hapishaneler krallığa ait olup, bu kurumların işletmesi "gaolers" olarak isimlendirilen iş insanlarına devredilmişti. Hapishanelerdeki ücret sistemi, bu kurumlara giren hükümlüden alınan "giriş ücreti" ve "tahliye ücreti" den oluşuyordu. Yine hükümlülerden hapishanelerde bulundukları süre içinde yiyecek, su ve yatak başta olmak üzere günlük ihtiyaçları için ücret alınıyordu. "Kullanıcı öder" ilkesinin erken ve kötü bir örneği olarak görülebilecek bu sistemin çeşitli biçimleri hükümlülerin Avustralya'ya nakledilmeye başlandığ 1780 'li y1llara kadar devam etmişti. ${ }^{40}$

İngiltere ve Galler'de ceza infaz kurumlarının özelleştirilmesine ilişkin tartışma 1980'lerin sonunda yeniden gündeme gelmeye başlamıştır. Bu kapsamda ceza infaz kurumlarının özel sektör tarafından yönetilebilmesi amaciyla yasal düzenleme yapılarak 1991 tarihli "Ceza Adaleti Kanunu" yürürlüğe girmiş, bu Kanununun kapsamı 1994 yılında genişletilerek İngiltere ve Galler'deki tüm ceza infaz kurumlarının özel sektör tarafından tasarlanabilmesi, inşa edilebilmesi, finanse edilebilmesi ve işletilebilmesi olanağı getirilmiştir. Ocak 2014 itibariyle, Bu Ülkede 14 özel sektör tarafından yönetilen ceza infaz kurumu bulunmaktadır. ${ }^{41}$

2013 y1lında İngiltere ve Galler'de, hükümlü ve tutukluların toplamının \% 16'sını oluşturan yaklaş1k 13.027 hükümlü özel sektör tarafından yönetilen ceza infaz kurumlarında barındırılmıştır. Amerika Birleşik Devletleri’nden

39 BUKET ABANOZ, Ceza İnfaz Kurumları'nda Özelleştirmenin Çok Boyutlu Değerlendirilmesi ve Türkiye'de Uygulanabilirliği, 2016, s.53-54, https://www.researchgate. net/publication/309451797_Ceza_Infaz_Kurumlari'nda_Ozellestirmenin_Cok_Boyutlu_ Degerlendirilmesi_ve_Turkiye'de_Uygulanabilirligi, erişim tarihi; 20.06.2021).

40 BROWN, a.g.m, s.104.

${ }^{41}$ ELENA KANTOROWICZ, Can Imprisonment be Cheaper? The Law and Economics of Private Prisons, 2014, s.5, (https://papers.ssrn.com/sol3/papers.cfm?abstract_id=2449265, erişim tarihi; 24.02.2021). 
farklı olarak İngiltere'de ceza infaz kurumlarını yöneten özel sektörle İçişleri Bakanlığı çok net, ölçülebilir kriterleri olan ve detaylı kuralları içeren sözleşmeler yapmaktadır. Bu sözleşmelerde; Devlet tarafından yönetilen ceza infaz kurumlarında uygulanan meslek ve rehabilitasyon programlarının özel sektör tarafindan yönetilen ceza infaz kurumlarında da uygulanması zorunlu olarak talep edilmektedir. Diğer yandan özel ceza infaz kurumlarında görevlendirilecek personelin çalışabilmesi için İçişleri Bakanlığı tarafından onay olarak isimlendirilen "yetkilendirme" işleminin yapılması gerekmektedir. Sözleşmede bu kuralların yanında özel sektör tarafından yönetilen ceza infaz kurumlarında istenilen performansın elde edilmesi amaciyla kurumun bulunduğu yerde görevli müfettişler tarafindan denetlenebileceği hükmü getirilmiştir. Ayrıca bu müfettişlerin hükümlülere uygulanan disiplin cezalarında da yetkileri bulunmaktadır. Yine özel sektör tarafından yönetilen ceza infaz kurumlarında kendileri için sözleşmede öngörülen hedeflere ulaşılamaması halinde firmanın ceza sorumluluğu ortaya çıkmaktadır. ${ }^{42}$

\section{Fransa'da Ceza İnfaz Kurumlarında Özelleştirme Uygulamaları}

1987 y1lında Fransa, 13.000 kişilik kapasiteye sahip yeni bir ceza infaz kurumunun özel sektör tarafından yapılması ve yönetilmesi amacıyla Amerikan ceza infaz kurumları özelleştirme modelini uygulanmayı planlamıştır. Ancak, bu konuda yapılan tartışmaların sonucu bu model yerine bir "karma yönetim" modeli kabul edilmiştir. Bu modele göre, ceza infaz kurumunun yapılması özel sektör tarafından gerçekleştirilmekte, ancak kurum Devlet tarafından yönetilmektedir. Bu modelde; yemeklerin hazırlanması, mesleki eğitim programların verilmesi ve sağlık hizmetleri gibi bir kısım faaliyetler için özel sektörle anlaşma yapılabilmektedir. Fransız Modelinde ceza infaz kurumlarının iç ve dış güvenliğinden sorumlu infaz ve koruma memurlarının kamu görevlisi olması gerekmektedir. ${ }^{43}$

$\mathrm{Bu}$ Ülkede başlangıç aşamasında; ceza infaz kurumlarının yemek ve temizlik faaliyetlerini kapsayan barınma hizmetleri, sağlık hizmetleri ve meslek eğitim çalışmaları özel sektör tarafından verilmiştir. Bu Modelde kamu görevlileri; kurumun yönetimini, iç ve dış güvenlik ile idari görevlerini yerine getirmektedir. Oransal olarak sisteme bakıldığında özel sektör personelinin tüm çalışanlara oranının \% 20 seviyesinde kaldığı anlaşılmaktadır. ${ }^{44}$

\footnotetext{
42 KANTOROWICZ, a.g.m, s.5.

43 KANTOROWICZ, a.g.m, s.6.

44 CABRAL VE SAUSSIER, a.g.m, s.107.
} 


\begin{tabular}{|l|c|c|c|c|c|}
\hline \multicolumn{7}{|c|}{ Fransız Ceza İnfaz Kurumlarının 1999-2003 Y1lları Aras1 } \\
Günlük Maliyeti (Avro ${ }^{45}$ \\
\hline & 1999 & 2000 & 2001 & 2002 & 2003 \\
\hline Özel Sektör Cezaevleri & 3.81 & 0.17 & - & 56.41 & 53.27 \\
\hline Kamu Cezaevleri & 3.73 & 5.12 & - & 52.00 & 45.83 \\
\hline Aradaki Fark & $\% 23$ & $\% 33.36$ & - & $\% 8.48$ & $\% 16.23$ \\
\hline
\end{tabular}

Fransız Modeline uygun ilk ceza infaz kurumu 1990 yılında yapılmıștır. 2009 y1lına kadar bu model uygulanarak yaklaşık 40 ceza infaz kurumu faaliyete geçmiş olup, bu kurumlarda Ülkedeki ceza infaz kurumlarında bulunan toplam hükümlü ve tutuklu sayısının \% 36'sı barındırılmıştır. 2010 yılında Fransa yeni bir özelleştirme programı başlatarak, 2012 yılında bu oranın \% 50'ye çıkarılmasını hedeflemiştir. ${ }^{46}$

\section{Avustralya'da Ceza İnfaz Kurumlarında Özelleştirme Uygulamaları}

Amerika Birleşik Devletleri'nden sonra Avustralya ceza infaz kurumlarını özel sektör tarafından yönetilmesi anlayışını benimseyen ikinci Ülkedir. ${ }^{47} \mathrm{Bu}$ Ülkede özel sektör tarafından yönetilen ilk ceza infaz kurumu 1990 yılında Queensland Eyaletindeki Borallon Ceza İnfaz Kurumu olup, bu ceza infaz kurumunun yapımı kamu tarafından tamamlandıktan sonra yönetimi özel sektöre devredilmiştir. Eyalet yönetimi; bu Model ile ceza infaz kurumlarına yapılan harcamaları düşürmeyi ve bu alanda rekabeti sağlamayı amaçlamıştır. $\mathrm{Bu}$ anlayış diğer eyaletler tarafindan da benimsenerek 1997-1998 yılları arasında özel sektör tarafından yönetilen onbeş ceza infaz kurumu faaliyete geçmiş ve bu kurumlarda Ülkedeki toplam hükümlü ve tutukluların \% 15.4’i barındırılmıştır. ${ }^{48}$

\footnotetext{
${ }^{45}$ CABRAL VE SAUSSİER, a.g.m, s.108.

46 KANTOROWICZ, a.g.m, s.6.

47 BROWN, a.g.m, s.104.

48 ANDREW BUSHNELL, Cutting Costs And Reducing Reoffending Redesigning Private Prison Contracts For Better Results, 2019, s.8, (https://ipa.org.au/wp-content/ uploads/2019/10/IPA-Cutting-costs-and-reducing-reoffending-Redesigning-private-prisoncontracts-for-better-results.pdf, erişim tarihi; 24.02.2021).
} 
Zamanla bu konudaki yoğun ilgi azalarak 2008-2009 yılları arasında Avustralya'da özel sektör tarafindan yönetilen ceza infaz kurumu sayıs1 yediye düşmüştür. Özel sektör tarafindan yönetilen ceza infaz kurumlarında barındırılan hükümlü ve tutuklu sayısının toplam hükümlü ve tutukluya oranı 1997-1998 döneminde \% 15.4 olarak gerçekleşirken, bu oran 2016-2017 döneminde $\% 18.4$ 'e yükselmiştir. ${ }^{49}$

Bu sistemde; Nisan 2019 da New South Wales bölgesinde bulunan Parklea Ceza İnfaz Kurumunun özel sektör tarafindan devir alınması ile yeni bir bakış açısı geliştirilmiştir. Özel sektörle yapılan sözleşmede performans kriterleri belirlenerek puanlama sistemi oluşturulmuş, bu kapsamda 25 temel performans göstergesi ile dört ayrı cezalandırma ölçüsü kabul edilmiştir. $\mathrm{Bu}$ sisteme göre aylık ödemeler belirlenmiştir. ${ }^{50}$

Ceza adaleti sisteminin bir parçası olan ceza infaz kurumlarının birkaç fonksiyonu bulunmaktadır. Bunlar; suça sürüklenen bireyleri ceza infaz kurumlarında tutmak, insan haklarına dikkat ederek hükümlülerin mahkemelerce verilen cezalarını infaz etmek, hükümlülerin tekrar suç işlemelerini önlemek ve rehabilitasyonlarını sağlamaktır. Bu Ülkede yapılan çalışmalarda özel sektör tarafından yönetilen ceza infaz kurumlarında ilk üç amaç; kamu tarafından yönetilen ceza infaz kurumlarından daha düşük maliyetle gerçekleştirildiği belirlenmiştir. Ancak uygulamada üzerinde durulan ve dikkate alınan konu, özel sektör tarafindan yönetilen ceza infaz kurumlarındaki rehabilitasyon çalışmalarının etkinliğidir. ${ }^{51}$

\section{E. Yeni Zelanda'da Ceza İnfaz Kurumlarında Özelleştirme Uygulamaları}

2000 yılında Yeni Zelanda ilk özel sektör tarafından yönetilen Auckland Central Ceza İnfaz Kurumu açılmıştır. Yeni Zelanda Parlamentosunca özel sektör tarafindan ceza infaz kurumlarının yönetilmesine izin veren kanunun kaldırıldığı 2005 yılının başlarına kadar ceza infaz kurumları özel sektör tarafindan yönetilmiştir. 2009'da Parlamentoda kabul edilen kanunla ceza infaz kurumlarının yeniden özel sektör tarafından yönetimine izin verilmiştir. Bu kapsamda 2011 y1lında Auckland Central Ceza İnfaz Kurumu tekrar özel sektör tarafından yönetilmeye başlanmıştır. Aynı yıl Mount Eden Ceza İnfaz Kurumu ve Mart 2012'de Eden Ceza İnfaz Kurumu aynı usulle idare

\footnotetext{
49 BUSHNELL, a.g.m, s.8.

50 BUSHNELL, a.g.m, s.10.

51 BUSHNELL, a.g.m, s.14.
} 
edilmiştir. Eden Ceza İnfaz Kurumu'nda Yeni Zelanda ceza infaz kurumlarında bulunan toplam 8.698 hükümlü ve tutuklunun yüzde 11'ini oluşturan 954 kişiyi barındırmıştır. Yine Eylül 2012'de, özel sektör tarafından yönetilecek 960 hükümlü ve tutuklu kapasiteli bir ceza infaz kurumunun inşaatına başlanmıştır. ${ }^{52}$

\section{F. Güney Afrika Cumhuriyeti'nde Ceza İnfaz Kurumlarında Özelleştirme Uygulamaları}

Güney Afrika Cumhuriyeti'nde 1997 y1lında özel sektör tarafindan dört ayrı ceza infaz kurumunun açılması planlamıştır. Bu kapsamda; 1999'da 3.024 kapasiteli Kutama-Sinthumule Ceza İnfaz Kurumu ile 2.928 kapasiteli Mangaung Ceza İnfaz Kurumu faaliyete geçmiştir. 2004 yılına kadar her iki ceza infaz kurumunda bu Ülkenin ceza infaz kurumlarında bulunan toplam 181.688 hükümlü ve tutuklunun \% 3'ü olan 5.952 hükümlü ve tutuklu barındırılmıştır. ${ }^{53}$

\section{G. Macaristan'da Ceza İnfaz Kurumlarında Özelleștirme Uygulamaları}

Macaristan'da 2004 y1l sonunda ceza infaz kurumlarının kapasitesinin $\% 40$ oranında artması sonucu kalabalıklaşma sorununun ortaya çıkması nedeniyle Ülkenin batısında bulunan Szombathely'de 15 y1l süre ile 700 hükümlü ve tutuklu kapasiteli bir ceza infaz kurumunun işletilmesi amacıyla özel sektörle anlaşma imzalamıştır. Yine özel sektör tarafindan işletilmesi amaciyla Ülkenin doğusunda Tiszalok'ta ikinci ceza infaz kurumunun inşası için ihale süreci başlatılmıştır. Özel sektör tarafından işletilen ceza infaz kurumlarının işletimi için yıllık yetmişaltı milyon avro ödenmesi planlanmıştır. $\mathrm{Bu}$ ceza infaz kurumlarında hükümlülerin kaydı ve tıbbi hizmetlerin dışında kalan hizmetlerin özel sektör tarafından verilmesi kararlaştırılmıştır. ${ }^{54}$

\section{H. Brezilya'da Ceza İnfaz Kurumlarında Özelleştirme Uygulamaları}

2008 y1lı sonu itibariyle yaklaşı 446.687 hükümlü ve tutuklu sayısı ile Brezilya Ceza İnfaz Kurumları Sistemi isyanları, firarları, yüksek yeniden

52 CODY MASON, International Growth Trends in Prison Privatization, 2013, s.8, (https:// sentencingproject.org/wp-content/uploads/2015/12/International-Growth-Trends-in-PrisonPrivatization.pdf, (erişim tarihi 23.02.2021).

53 MASON, a.g.m, s.9.

54 STEPHEN NATHAN, The European Market for Privatised Correctional Services: Developments and Implications, 2005, s.3, (https:/www.epsu.org/sites/default/files/article/ files/PSIRUprisonreport2005.pdf, erişim tarihi; 23.02.2021). 
suç işleme oranları ve aşırı kalabalıklaşma sorunları ile bilinmekteydi. $\mathrm{Bu}$ sorunların çözülmesi amacıyla ceza infaz kurumlarının özel sektöre devredilmesine karar verilmiştir. Bu konuda gerçekleştirilen yoğun tartışmalar sonunda kamunun ceza infaz kurumunun yönetiminden ve dış güvenliğinden sorumlu olması, buna karşın özel sektörün iç güvenlik, yemek, sağlık hizmetleri, eğitim çalışmaları, kurumun yönetimi ve taşıt araçlarının temini işlerinden sorumlu bulunması kabul edilmiştir. ${ }^{55}$

Brezilya Modeli olarak adlandıran bu Model; Fransız tecrübesinden esinlenmiş olsa da, Modelde Fransız Modelinde bulunmayan iç güvenlik ve hukuki yardım gibi hizmetlerin özel sektöre devredilmesi nedeniyle Fransız Modeli ile Amerika Birleşik Devletleri Modeli arasında bulunduğu değerlendirilmektir. ${ }^{56}$

Brezilya Ceza İnfaz Kurumlarında 2002-2005 Yılları Arası Ölüm ve Firar Sayıs1 ${ }^{57}$

\begin{tabular}{|c|c|c|c|c|c|c|}
\hline & & 2002 & 2003 & 2004 & 2005 & Ortalama \\
\hline \multirow{2}{*}{ Ölüm } & $\begin{array}{l}\text { Kamu } \\
\text { Cezaevleri }\end{array}$ & 8 & 5 & 8 & 6 & 6.8 \\
\hline & $\begin{array}{l}\text { Özel } \\
\text { Cezaevleri }\end{array}$ & 0 & 7 & 2 & 3 & 3 \\
\hline \multirow{2}{*}{ Firar } & $\begin{array}{l}\text { Kamu } \\
\text { Cezaevleri }\end{array}$ & 3 & 0 & 2 & 6 & 2.8 \\
\hline & $\begin{array}{l}\text { Özel } \\
\text { Cezaevleri }\end{array}$ & 0 & 0 & 0 & 1 & 0,3 \\
\hline \multirow{2}{*}{$\begin{array}{l}\text { Her Ceza İnfaz } \\
\text { Kurumunun } \\
\text { Ortalama } \\
\text { Mevcudu }\end{array}$} & $\begin{array}{l}\text { Kamu } \\
\text { Cezaevleri }\end{array}$ & 636.6 & 626.5 & 671.5 & 694.7 & 657.3 \\
\hline & $\begin{array}{l}\text { Özel } \\
\text { Cezaevleri }\end{array}$ & 337.5 & 402.5 & 42.5 & 447.3 & 402.5 \\
\hline
\end{tabular}

\section{III.DENETIMLİ SERBESTLİK SİSTEMINDE ÖZEL SEKTÖR ÇALIŞMALARI}

İnfaz sistemi; hapis cezaları ve denetimli serbestlik tedbirleri başlıkları

\footnotetext{
${ }^{55}$ CABRAL VE SAUSSIER, a.g.m, s.109.

56 CABRAL VE SAUSSIER, a.g.m, s.109.

57 CABRAL VE SAUSSIER, a.g.m, s.110.
} 
altında incelenebilir. ${ }^{58}$ Denetimli serbestlik; soruşturma aşamasında şüpheliler, kovuşturma aşamasında sanıklar hakkında "sosyal araştırma raporu" hazırlanması, mahkemelerce tutuklama tedbiri yerine verilen adli kontrol tedbirinin, kısa süreli hapis cezası yerine hükmedilen seçenek tedbirlerin infaz edilmesi, uyuşturucu veya uyarıcı madde kullanan veya bulunduran sanıkların rehabilitasyonunun sağlanması, mahkemelerce hapis cezasının ertelenmesi veya koşullu salıvermeye karar verilmesi halinde hükümlülere görevlendirilen rehber ve/veya yüklenen yükümlülüklerin yerine getirilmesi, ceza infaz kurumlarından salıverilen hükümlülerin topluma kazandırılmasına destek olunması, mahkemelerce suça sürüklenen çocukların denetim altına alınması halinde bu kararın infaz edilmesi ve ceza infaz kurumunda bulunan hükümlülere iş arama sürecinde yardım yapılması çalışmalarını kapsayan bir sistemdir. ${ }^{59} \mathrm{Bu}$ kapsamda fotoğrafın tamamının görülebilmesi amacıyla, infaz sisteminin diğer bir boyutunu oluşturan denetimli serbestlik ile ilgili özel sektör çalışmaları konusunun kısaca incelenmesi gerekmektedir.

Amerika Birleşik Devletleri'nde ve Kanada'da denetimli serbestlik çalışmaları genellikle kamu tarafından yerine getirilmektedir. Ancak Amerika Birleşik Devletleri'nin bazı eyaletlerinde özel sektörün denetimli serbestlik kararlarının yerine getirilmesi çalışmalarına katıldığı görülmektedir. Dünyada özel sektör tarafından denetimli serbestlik sistemi kapsamında takip edilen hükümlü sayısı bilinmemekle beraber, son yıllarda bu uygulamaya karşı büyük bir ilgilinin olduğu anlaşılmaktadır. Özellikle denetimli serbestlik kapsamında verilen para cezalarının tahsili için özel sektör çalışmaları bulunmaktadır. Akademik alanda temel tereddüttün, özel sektörün denetimli serbestlik

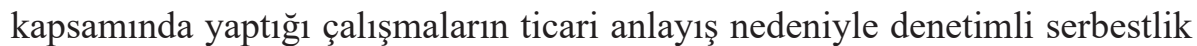
sisteminin felsefesine ve amacına zarar verip vermeyeceği noktasında toplanmaktadır. ${ }^{60}$

Avrupa'da; özel sektör tarafından denetimli serbestlik kararlarının yerine getirilmesi, diğer ifade ile denetimli serbestlik sisteminde özelleştirme uygulamaları konusunda İngiltere liderlik yapmaktadır. Bu Ülkede denetimli

58 VEHBİ KADRİ KAMER, “Ceza Adalet ve İnfaz Sistemi İçinde Denetimli Serbestlik Sisteminin Önemi”, Adalet Dergisi, Sayı: 31, 2008, s.1.

59 VEHBİ KADRİ KAMER, Kriminoloji (Suç Sosyolojisi), Ankara Açık Ceza Kurumu Matbaas1, Ankara, 2017, s.288.

60 JAMES BYRNE, KIMBERLY R. KRAS, LINA MARİA MARMOLEJO, 2019, International perspectives on the privatization of corrections, s.485, (https://spa.sdsu.edu/ documents/Byrne_et_al-2019-Criminology_Public_Policy.pdf, erişim tarihi; 24.02.2021). 
serbestlik sisteminin \% 70'ini özel sektör takip etmektedir. ${ }^{61}$ İngiltere'de 2013 yılında Adalet Bakanlığ1 "Ulusal Denetimli Serbestlik Servisinde" "Rehabilitasyona Dönüş I" politikasını yürürlüğe koyarak 35 denetimli serbestlik bölge müdürlügünü kaldırmış, yerine 21 denetimli serbestlik bölgesi oluşturarak kar amacı olan "Toplumsal Rehabilitasyon Şirketleri" ile denetimli serbestlik işlemlerinin yerine getirilmesi kapsamında sözleşme yapma imkanı getirmiştir. $\mathrm{Bu}$ modelde; "Toplumsal Rehabilitasyon Şirketlerince" denetimli serbestlik altına alınan düşük ve orta risk taşıyan hükümlülerin, Adalet Bakanlığ1 "Ulusal Denetimli Serbestlik Servisince" yüksek risk taşıyan hükümlülerin denetlenmesi ve tedbirlerin infaz edilmesi esası benimsenmiştir. 2015 yılında sekiz konsorsiyumdan oluşan bir oligopol ile 2022 yılına kadar tüm denetimli serbestlik hizmetlerinin yürütülmesi konusunda bir sözleşme imzalanmıştır. 2019 yılına kadar bu yeni sistemle ilgili çok sayıda araştırma ve rapor hazırlanmış, bunun sonucunda Bakanlık özel sektörle yapılan sözleşmelerin erken sona erdireceğini, bu kapsamda düşük ve orta risk taşıyan hükümlülerin denetiminin Adalet Bakanlığ "Ulusal Denetimli Serbestlik Servisince” yapılacağını açıklamıştır. 11 Haziran 2020 tarihinde Adalet Bakanının Parlamento'da yaptığı açıklamada Haziran 2021 yılına kadar tüm denetimli serbestlik çalışmalarının kamu tarafından yerine getirileceğini ifade etmiştir. ${ }^{62}$

\section{DEĞERLENDİRME}

Dünyada ceza infaz kurumlarının özel sektör tarafindan yönetilmesi ile ilgili üç ayrı model bulunmaktadır. Bunlardan Birinci Modelde; Amerika Birleşik Devletleri, Birleşik Krallık, Avustralya ve Güney Afrika' da özel sektör ceza infaz kurumunu inşa etmekte ve yönetmektedir. Íkinci Modelde; Fransa, Macaristan, Latin Amerika'nın bazı bölgeleri ve Japonya'da özel sektör ceza infaz kurumunun inşasını finanse etmekte ayrıca bu kurumdaki sağlık, yemek ve rehabilitasyon çalışmaları gibi belli hizmetleri yerine getirmektedir. U̧̧̧йncü Modelde Hollanda ve bir kısım Avrupa ülkelerinde ceza infaz kurumundaki hükümlü nakli, yemek, rehabilitasyon çalışmaları gibi bir kısım hizmetler özel sektör tarafindan yerine getirilmektedir. ${ }^{63}$

${ }^{61}$ BYRNE, KRAS, MARMOLEJO, a.g.m, s.485.

${ }_{62}$ MARY CORCORAN, Finding the Eye of the Octopus: the Limits of Regulating Outsourced Offender Probation in England and Wales, 2021, s.1, (file:///C:/Users/ab33992/Downloads/ rfcb-7888.pdf erişim tarihi; 06.03.2021)

63 BYRNE, KRAS, MARMOLEJO, a.g.m, s.498. 
Özbek, ceza infaz kurumlarının özelleştirilmesinin üç ayr1 yöntemle gerçekleşebileceğini ileri sürmüştür. $\mathrm{Bu}$ yöntemlerin birincisi, ceza infaz kurumlarının yapımının ve işletmesinin tamamen özel sektöre devredilmesi, ikincisi, hükümlü ve tutukluların barındırılması, iaşelerinin sağlanması, eğitim, sağlık ve kültürel ihtiyaçlarının giderilmesinin özel sektör tarafından yerine getirilmesi, üçüncüsü, ceza infaz kurumlarındaki iş gücünün kar amaçlı özel sektör tarafindan değerlendirilmesidir. ${ }^{64}$

Ceza infaz kurumlarının özel sektör tarafından yönetilmesi veya bu kurumlardaki bazı çalışmaların özel sektör tarafından sürdürülmesi konusunda yapılan araştırmalar incelendiğinde ${ }^{65}$;

1. Alonso ve Andrews tarafindan İngiltere'de 2016 y1lında 99'u kamu tarafindan 15'i özel sektör tarafindan yönetilen ceza infaz kurumunda yapılan araştırmada; özel sektör tarafindan yönetilen ceza infaz kurumları ölçülmesi kolay kalabalıklaşma, firar gibi güvenlik alanlarında, kamu tarafından yönetilen ceza infaz kurumlarının ise ölçülmesi zor hükümlünün günlük aktiviteleri, uyuşturucu testleri ve saldırı gibi güvenlik alanlarında daha iyi sonuçlar verdiği,

2. Bales ve diğerleri tarafindan Amerika Birleşik Devletleri Florida Eyaletinde 2005 yılında kamu ve özel sektör tarafindan yönetilen ceza infaz kurumlarında bulunan 81.737 yetişkin kadın ve erkek hükümlü ile genç erkek hükümlü ile ilgili yapılan araştırmada yönetim şekli farklı iki ayrı kurumdan salıverilen hükümlülerin yeniden suç işleme oranları konusunda önemli bir farklılığın olmadığı,

3. Duwe ve Clark tarafindan Amerika Birleşik Devletleri Minnesota Eyaletinde 2013 yılında özel sektör tarafından yönetilen ceza infaz kurumlarından salıverilen 3.532 hükümlü ile ilgili yapılan araştırmada bu kurumdan salıverilen hükümlülerin yeniden suç işleme oranlarının daha yüksek olduğu,

4. Farabee ve Knight tarafindan Amerika Birleşik Devletleri Florida Eyaletinde 2002 yılında özel sektör tarafından yönetilen ceza infaz kurumlarından salıverilen 8.848 yetişkin ve genç erkek hükümlü ile ilgili ceza infaz kurumundan salıverildikten sonra yeniden suç

64 VELİ ÖZER ÖZBEK, İnfaz Hukuku, Seçkin Yayınevi, Ankara, 2013, s.281.

65 BYRNE, KRAS, MARMOLEJO, a.g.m, s.494. 
işleme oranları konusunda yapılan araştırmada, özel sektör ve kamu tarafından yönetilen ceza infaz kurumları arasında önemli bir faklılığın olmadı ̆̆

5. Pratt ve Maahs tarafindan Amerika Birleşik Devletleri'nde 1999 yılında özel sektör ve kamu tarafindan yönetilen ceza infaz kurumlarında hükümlülerin günlük maliyeti konusunda yapılan bir araştırmada, özel sektör tarafından yönetilen ceza infaz kurumlarının kamu tarafindan yönetilen ceza infaz kurumların nazaran çok fazla ekonomik bulunmadığ 1 ,

tespit edilmiştir.

$\mathrm{Bu}$ araştırma ve değerlendirme sonucunda ceza infaz kurumlarının özel sektör tarafından yönetilmesi sisteminde sorunların önlenebilmesi için üç ayrı tedbir alınması gerektiği vurgulanmıştır. Bu tedbirlerden birincisi, özel sektör ile yapılan sözleşmelerde belirli standartların yer alması, ikincisi, etkin bir denetim sisteminin oluşturulması ve üçüncüsüu, sözleşmenin ihlali ve şirketin iflası halinde alternatif düzenlemeler yapılmış olmasıdır. ${ }^{66}$

Sonuç olarak Dünyada ceza infaz kurumlarının özel sektör tarafından yönetilmesi konusunda çok sayıda araştırma yapılması gerekmektedir. $\mathrm{Bu}$ kapsamda başta; ceza infaz kurumlarında eğitim ve rehabilitasyon çalışmaları, meslek eğitim çalışmaları, ceza infaz kurumlarında salıverilen hükümlülerin yeniden suç işleme oranları, ceza infaz kurumlarındaki saldırı, firar, intihar gibi asayiş olayları, sağlık hizmetleri, hükümlülerin aileleri ile telefon, mektup ve ziyaret ile münasebetleri, nakil, personel sayısı, teknoloji kullanımı, maliyet gibi konularda hem ayrı ayrı ülkeler hem de Dünya ölçeğinde karşılaştırmalı çalışmaların yapılması gerekmektedir. Aksi takdirde haklarında hapis cezası verilen suça sürüklenen bireylerin diğer ifade ile hükümlülerin topluma kazandırılması çalışmalarında ceza infaz kurumlarının özel sektör tarafından yönetiminin ne kadar etkili olduğu anlaşılamayacaktır.

${ }^{66}$ GÖRKEM, a.g.e, s.18. 


\section{KAYNAKÇA}

Abanoz, B., Ceza İnfaz Kurumları'nda Özelleştirmenin Çok Boyutlu Değerlendirilmesi ve Türkiye'de Uygulanabilirliği, https://www. researchgate.net/publication/309451797_Ceza_Infaz_Kurumlari'nda_ Ozellestirmenin_Cok_Boyutlu_Degerlendirilmesi_ve_Turkiye'de_ Uygulanabilirligi, erişim tarihi; 20.06.2021).

Aman A. C, Jr ve Carol, J., "Greenhouse, Prison Privatization And Inmate Labor In The Global Economy: Reframing The Debate Over Private Prisons", 2016, Vol:42, Fordham Urban Law Jurnal, s.355-409, (https:// ir.lawnet.fordham.edu/cgi/viewcontent.cgi?article $=2561 \&$ context $=\mathrm{ulj}$, erişim tarihi; 24.02.2021).

Blakely C. R ve Bumphus V. W, Private and Public Sector Prisons-A Comparison of Select Characteristics, s.4, (https://www.uscourts.gov/ sites/default/files/68_1_5_0.pdf, erişim tarihi; 24.02.2021).

Brown A., Economic Aspects Of Prison Privatisation: The Queensland Experience, s.104 (http://citeseerx.ist.psu.edu/viewdoc/download?doi=1 0.1.1.491.4922\&rep=rep1\&type=pdf, erişim tarihi; 24.02.2021).

Bushnell A., Cutting Costs And Reducing Reoffending Redesigning Private Prison Contracts For Better Results, 2019, s.8, (https://ipa.org.au/wpcontent/uploads/2019/10/IPA-Cutting-costs-and-reducing-reoffendingRedesigning-private-prison-contracts-for-better-results.pdf, erişim tarihi; 24.02.2021).

Butorac K, Gracin D ve Stanić N, 2017, The Challenges In Reducıng Crımınal Recidivism, s.115-131, (https://bib.irb.hr/datoteka/912525.Butorac_et_ al.pdf, erişim tarihi; 24.02.2021).

Byrne J, Kras K R ve Marmolejo L M, "International perspectives on the privatization of corrections", 2019, Criminology ve Public Polic, s.477503, (https://spa.sdsu.edu/documents/Byrne_et_al-2019-Criminology Public_Policy.pdf, erişim tarihi; 24.02.2021).

Cabral S. ve Saussier S, Organizing Prisons Through Public-Private Partnerships: A Cross Country Investigation, 2012, s.100-120, (https:// www.researchgate.net/publication/262665166_Organizing_Prisons_ through_Public-private_Partnerships_A_Cross-Country_Investigation/ link/0395bde90cf2005ef799de40/download, erişim tarihi; 24.02.2021). 
Corcoran M, Finding the Eye of the Octopus: the Limits of Regulating Outsourced Offender Probation in England and Wales, 2021, s.1, (file:///C:/Users/ab33992/Downloads/rfcb-7888.pdf erişim tarihi; 06.03.2021)

Delisi M., Conis P J, American Corrections: Theory, Research, Policy, and Practice, 2019, s.58, (https://us.sagepub.com/sites/default/files/upmassets/94917_book_item_94917.pdf, erişim tarihi; 24.02.2021).

Demirbaş T, İnfaz Hukuku, Seçkin Yayınevi, Ankara, 2003.

Görkem, H., Kamu Hizmetlerinin Özelleştirilmesi Kapsamında Cezaevi Hizmetlerinin Özelleştirilmesi ve Türkiye'de Uygulanabilirliği, Ankara, 2009.

Kamer V. K, “2015 Y11ı İlk Beş Ayında İşyurtları Kurumu”, 2015, Sayı:158, Sesleniş Gazetesi, s.1-16.

Kamer V. K, "Ceza Adalet ve İnfaz Sistemi İçinde Denetimli Serbestlik Sisteminin Önemi”, 2008, Sayı: 31, Adalet Dergisi, s.69-80.

Kamer V. K, "Ceza İnfaz Sisteminde "İyi Hâl" Kararı İle "Değerlendirme Raporu”-I”, 2013, Say1:165, Sesleniş Gazetesi, s.1-16.

Kamer V. K, Kriminoloji (Suç Sosyolojisi), Ankara Açık Ceza Kurumu Matbaası, Ankara, 2017.

Kantorowicz E. ve Wibisana A. Rotterdam Institute of Law and Economics (RILE) Working Paper Series, 2014, s.1-50, (https://papers.ssrn.com/ sol3/papers.cfm?abstract_id=1116188, erişim tarihi; 24.02.2021).

Kantorowicz E., "Can Imprisonment be Cheaper? The Law and Economics of Private Prisons", Forthcoming in the European Journal of Law Reform 2016, 2014, s.5, (https://papers.ssrn.com/sol3/papers.cfm?abstract_ id $=2449265$, erişim tarihi; 24.02.2021).

Khatun N., Islam M J., Banarjee S. ve Paul M, Philosophy of Punishment in Criminology: A Historical Review, 2013, s.1-19, (https://www. researchgate.net/publication/330113779_Philosophy_of_Punishment_ in_Criminology_A_Historical_Review, erişim tarihi; 24.02.2021).

Maculan A., Ronco D. ve Vianello F., Prison in Europe: Overview And Trends, 2013, s.5-62, (http://www.prisonobservatory.org/upload/ 
PrisoninEuropeOverviewandtrends.pdf, erişim tarihi; 24.02.2021).

Mason C, International Growth Trends in Prison Privatization, 2013, s.8, (https://sentencingproject.org/wp-content/uploads/2015/12/ International-Growth-Trends-in-Prison-Privatization.pdf, (erişim tarihi 23.02.2021).

Nathan S, The European Market for Privatised Correctional Services: Developments and Implications, 2005, s.3, (https://www.epsu.org/sites/ default/files/article/files/PSIRUprisonreport2005.pdf, erişim tarihi; 23.02.2021).

Odabaşı, L., Cezaevi Endüstrileri ve Cezaevi Özelleştirilmesi, Ankara Üniversitesi Sosyal Bilimler Enstitüsü Siyaset Bilimi ve Kamu Yönetimi (Siyaset Bilimi) Yayınlanmamış Yüksek Lisans Tezi, Ankara, 2016.

Özbek, V. Ö, İnfaz Hukuku, Seçkin Yayınevi, Ankara, 2013.

Pozen D., "Managing a Correctional Marketplace: Prison Privatization In The United States and The United Kingdom", 2004, V:19, Journal of Law ve Politics, s.251-286, (https://scholarship.law.columbia.edu/faculty_ scholarship/1305, erişim tarihi; 24.02.2021).

Sanchez S., Street Crime, Corporate Crime, and White-Collar Crime, (https:// openoregon.pressbooks.pub/ccj230/chapter/1-12-different-types-ofcrime-in-the-united-states/, erişim tarihi; 24.02.2021). 
